\title{
臭気物質の嗅覚閾値と飽和蒸気圧の相関性
}

\author{
大 迫 政 浩*1, 西 田 耕之助*2 \\ *1国立公衆衛生院衛生工学部，*2京都大学工学部附属環境微量污染制御実駼施設
}

\section{Correlation between Odor Thresholds and Saturated Vapor Pressures of Odorants}

\author{
Masahiro Osako*1 and Konosuke Nishida*2 \\ ${ }^{*}$ Department of Sanitary Engineering, The Institute of Public Health, Tokyo \\ ${ }^{* 2}$ Laboratory for Control of Environmental Micropollutants, Faculty of Engineering, Kyoto University, Otsu
}

\begin{abstract}
The purpose of our work is to develop an estimation method for odor thresholds on the basis of physicochemical properties of odorous compounds. In this report, we examined the correlation between odor thresholds $\left(\mathrm{C}_{\mathrm{th}}\right)$ and the saturated vapor pressures $\left(\mathrm{P}_{\mathrm{vp}}\right)$ of various odorants.

Results.

1 ) There were very good correlations between $P_{v p}$ and k. k represents an indicator of lipid affinity. In our earlier report, $\mathrm{k}$ was obtained by the analysis of the gas chromatography with a column packed with a support coated by a phospholipid. Accordingly the correlations show that $\mathrm{P}_{\mathrm{vp}}$ may be an indicator of solubility into the lipid phase.

2 ) It was found that correlations between $\mathrm{P}_{\mathrm{vp}}$ and $\mathrm{C}_{\text {th }}$ were very good in several homologous series of aliphatic compounds. However inoized substances, such as acids and amines, and sulfur compounds had no good correlations.

3 ) In odorants having more than $3 \sim 5$ carbon atoms, odor thresholds of normal types were higher than those of iso types.

4 ) In the series of amines, the relationship between $\mathrm{C}_{\text {th }}$ and $\mathrm{P}_{\mathrm{vp}}$ depended upon the length and the number of alkyl chains combined with the contained nitrogen atom.

5 ) In the series of alcohol and aldehyde, the decrease of $\mathrm{C}_{\mathrm{th}}$ in the rate became smaller with the decrease of $\mathrm{P}_{\mathrm{vp}}$.
\end{abstract}

Key words: Odorant, Odor threshold, Solubility into lipid phase, Saturated vapor pressure 臭気物質, 嗅覚間值, 脂質溶解能, 飽和蒸気圧

\begin{abstract}
緒

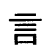

近年, 臭気事象の感覚的評価法が重要視され, 三点比 較式臭袋法による臭気濃度の測定 ${ }^{1)}$ や, 臭気強度および 快・不快度の評定尺度法に上る評価 ${ }^{2)}$ が行われている。 また，ガスクロマトグラフ分析などによる機器分析も補 完的に行われ，それらの結果と感覚的評価法による結果 を総合した臭気事象の把握が必要である。

また，このようにして臭気事象を評価する場合には, 臭気の構成成分の嗅覚閾値 (以下, 閾值と略す)を把握す ることが重要で, 閾值から成分間の感覚的寄与性や臭気
\end{abstract}

濃度を推測することも可能である。しかしながら，現在 までに信頼性の高い閾值データの集積は十分でなく，ま た，実際に閾値を測定する場合においても，多大な労力 を必要とする場合が少なくない。

そこで本研究では, 臭気の評価において重要な要素で ある臭気物質の閾値を物理化学的特性から予測する手法 について検討した。

Leonardos ${ }^{3)}$ は，53種類の臭気物質の閾值濃度を測定 し, 化学構造や化学作用からの閾値の予測の可能性が極 めて低いと述べた。これに対してDravnieks ${ }^{4)}$ は，同族 列内では閾值濃度と飽和蒸気圧の比が系統的に变化する 
ことを認めた。すなわち，炭素数が $4 \sim 5$ までは比は減 少し，それ以上だと大きくなると述べている。また， Dravnieks $^{5)}$ は29種の臭気物質の間值濃度を測定し， Building-Block モデルによる回帰分析を行った。Laffort ${ }^{6)}$ は，文献から得られた閾值を正規化したものと，分子容 や水溶解度などのパラメータが相関性があることを認め た。しかしながら，これらの解析に用いられた閾值のデー 夕は, 文献值の場合がほとんどで，測定方法の不統一性 などの点からデータ自体の精度が問題とされた。

近年, 栗原らの生理学的研究 7)8)により, 脂質への溶 解性と閾值との間に相関性があることが指摘され，さら に，岡畑 ${ }^{9)}$ は，人工的に作られた脂質二分子膜，および 嗅上皮細胞に対する臭気物質の分配係数と閾值との間に 良い相関があることを見いだしている。

大迫ら ${ }^{10)}$ は, 多種の臭気物質の間值を実際に測定し, 閾值が嗅細胞膜の脂質層への吸着能(親和性)と関連性が あることを見いだした。すなわち，リン脂質をコーティ ングした吸着剂への吸着能をガスクロマトグフ分析によ る保持時間によって評価し, 脂肪族化合物類において, 官能基が共通する同族列内では保持時間と閾値の間に高 い相関性があることを認めた。しかし，ガスクロマトグ ラフの利用において, 移動相の流速および設定温度など の条件の制限による検出感度の問題から，典型的な悪臭 物質であるアミン類や脂肪酸類についての検討が困難で あった。

そこで本研究では，脂質親和性指標として，脂質様の 無極性物質に対する溶解能の指標である飽和蒸気圧が適 用できることを説明し，アミンおよび脂肪酸類も含めて， 種々の臭気物質の閾値との相関性を詳細に検討した。

\section{解析方法}

1. 嗅覚閾値データ

本解析において用いる間值のデータには，すでに大迫 らの実験的研究 ${ }^{10)}$ において測定された135種の臭気物質 に, 若干のデータを新たに測定して付け加え, アルカン 類 11 種, アルコール類 17 種, ケトン類 13 種, アルデヒド 類 11 種, エステル類 41 種, 脂肪酸類 8 種, 芳香族類 21 種, 硫黄化合物 10 種およびアミン類 11 種の計 143 種類のデー タを用いた。

なお，閾值データは，三点比較式臭袋法(排出口測定 $)^{1)}$ による検知閾値のデータである。

2 . 飽和蒸気圧の推定方法 飽和蒸気圧 $P_{v p}(\mathrm{mmHg})$ は, 次式で与えられている Antoine 式11)を用いて推定した。 1n $\mathrm{P}_{\mathrm{vp}}=\mathrm{A}-\mathrm{B} /(\mathrm{T}+\mathrm{C})$
$\mathrm{A}, \mathrm{B}, \mathrm{C}$; 物質に固有の定数
$\mathrm{T} ;$ 絶対温度 $(\mathrm{K})$

(1)式は, 精度の高い推算式として広く用いられており 定数 A , B , C も多〈の物質について求められている ${ }^{12)}$

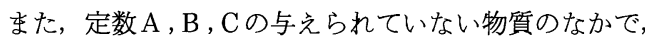
数段階の温度に対する飽和蒸気圧の実測值が報告されて いる場合には，次式で与えられるClausius-Clapeyron ${ }^{11)}$ 式への回帰結果から $\mathrm{P}_{\mathrm{vp}}$ を求めた。

1n $\mathrm{P}_{\mathrm{vp}}=\mathrm{D}-\mathrm{E} / \mathrm{T}$

$\mathrm{D}, \mathrm{E} ;$ 物質に固有の定数

なお，飽和蒸気圧 $\mathrm{P}_{\mathrm{vp}}$ は, $\mathrm{T}=298.15(\mathrm{~K})\left(25^{\circ} \mathrm{C}\right)$ にお ける推定値とした。

このように, 飽和蒸気圧は多くの臭気物質に対してデー タが集積されており，文献的に容易に検索できる点で， 閾值を予測する物理化学的指標として有利である。

3 . 嗅覚閾値之飽和蒸気圧の相関性の検討

臭気物質の脂質層への吸着性, あるいは溶解性は, 物 質の基本骨格や官能基などによって傾向が異なると考え られることから, 各物質群ごとに閾値と飽和蒸気圧の相 関性を検討し，両者の詳細な傾向を抽出した。

\section{解析結果および考察}

1. 脂質への吸着, 溶解性指標としての飽和蒸気圧 (理 想溶解度）

溶質成分の溶媒への溶解度を推定する方法として, 次 式で表される理想溶解度 ${ }^{11)}$ がある。

$$
\mathrm{x}=\frac{\mathrm{P}}{\mathrm{P}_{\mathrm{vp}}} \cdot \mathrm{y}
$$

$\mathrm{x}=$ 液相溶質モル分率 $\mathrm{y}=$ 気相溶質モル分率

$\mathrm{P}:$ 全圧 $(\mathrm{mmHg}) \quad \mathrm{P}_{\mathrm{vp}}$ : 飽和蒸気圧 $(\mathrm{mmHg})$

(3)式は, 無極性, 無限希釈状態の理想溶液に適用され る式で, $\mathrm{P} / \mathrm{P}_{\mathrm{vp}}$ は温度の関数であるが溶媒の種類には依 存しない。したがって, 脂質層の構成成分であるリン脂 質のような高分子の極性の低い物質を溶媒とした場合に も，(3)式はある程度適用しうると考えられる。市た(3)式 から， $\mathrm{P}_{\mathrm{vp}}$ は溶解度を表す指標であり, 気相濃度が一定 であれば， $\mathrm{P}_{\mathrm{vp}}$ が小さい物質ほど液相への溶解度が大き くなる。

ここで, 鼻腔内に気相濃度が閾值濃度 $\mathrm{C}_{\mathrm{th}}$ の臭気ガス が吸入され, 嗅細胞中の脂質層へ溶解し, 直ちに平衡状 態に達したとする，そのときの脂質層内の臭気物質濃度 を $\mathrm{A}_{0}$ として，リン脂質を溶媒とする場合に(3)式が成立 すると仮定すると， 


$$
\mathrm{A}_{0}=\frac{\mathrm{P}}{\mathrm{P}_{\mathrm{vp}}} \cdot \mathrm{C}_{\mathrm{th}}
$$

そこで, 嗅細胞に受容器電位を発生させるために必要 な脂質層内の臭気物質濃度が一定 $\left(\mathrm{A}_{0}\right.$ が一定 $)$ であると 考えると，(4)式から $\mathrm{P}_{\mathrm{vp}}$ と $\mathrm{C}_{\mathrm{th}}$ の間には比例関係が成立 することになる。

前述のように, Dravnieks ${ }^{4)}$ は同族列内で間値と飽和 蒸気圧の比が系統的に变化すると報告したが，飽和蒸気 圧が嗅覚における生理的機能とどのように関係している かについては明言されていない。これに対して本研究で は，飽和蒸気圧が臭気物質の脂質層への溶解性指標とな り得る可能性があることを理論的に説明した。

2.ガスクロマトグラフ分析を利用した脂質親和性指標

\section{と飽和蒸気圧との関連性}

大迫ら ${ }^{10)}$ は，リン脂質をコーティングした吸着剤の 充媜カラムを装着したガスクロマトグラフ分析によって, 各臭気物質の保持時間を測定し，脂質親和性指標 $\mathrm{k}$ を提 案した。また，脂肪族化合物類については， $\mathrm{k}$ と閾値と の間に次式で表される相関関係が存在することを明らか にした。

$$
\log \frac{1}{\mathrm{C}_{\mathrm{th}}}=\mathrm{a} \log \mathrm{k}+\mathrm{b}
$$

$$
\begin{aligned}
(\mathrm{k}= & \left.\frac{\mathrm{t}_{\mathrm{R}}-\mathrm{t}_{0}}{\mathrm{t}_{0}}\right) \\
& \mathrm{t}_{\mathrm{R}} ; \text { 対象物質の保持時間 } \\
& \mathrm{t}_{0} ; \text { マーカーの保持時間 } \\
& \mathrm{a}, \mathrm{b} ; \text { 定数 }
\end{aligned}
$$

(5)式は，分配係数 $\pi$ と $\mathrm{k}$ の間に成立する一般式 ${ }^{13)}(6)$ 式から導かれたものである。

$$
\begin{gathered}
\log \pi=\mathrm{c} \log \mathrm{k}+\mathrm{d} \\
\mathrm{c}, \mathrm{d} \text {; 定数 }
\end{gathered}
$$

したがって， $\mathrm{k}$ は気相一脂質系での分配係数を表す指 標としての意味をもつ。また，ここで，(4)式の $\mathrm{P} / \mathrm{P}_{\mathrm{vp}}$ は， 気相と溶媒間の臭気物質の分配係数と考它られるから, (6)式の $\pi$ を $\mathrm{P} / \mathrm{P}_{\mathrm{vp}}$ に置き換えて，

$$
\begin{gathered}
\log \frac{\mathrm{P}}{\mathrm{P}_{\mathrm{vp}}}=\alpha \log \mathrm{k}+\beta \\
\log \frac{1}{\mathrm{P}_{\mathrm{vp}}}=\alpha \log \mathrm{k}+\beta^{\prime} \\
\left(\beta^{\prime}=\beta-\log \mathrm{P}\right)
\end{gathered}
$$

したがって， $\mathrm{P}_{\mathrm{vp}}$ と $\mathrm{k}$ の間に(8)式が成立すれば， $\mathrm{P}_{\mathrm{vp}}$ は脂質への吸着能を表す指標とみなすことができる。

Table 1 K各臭気物質の閾値 $\left(\mathrm{C}_{\mathrm{th}}\right)^{10)}$ と，(1)式および(2) 式から推定された飽和蒸気圧 $\mathrm{P}_{\mathrm{vp}}$ を示す。そこで, $\mathrm{P}_{\mathrm{vp}}$

Table 1 Odor thresholds $\left(C_{\text {th }}\right)$ and saturated vapor pressures $\left(P_{v p}\right)$

\begin{tabular}{lll||lll}
\hline Serial No. Odorant & $\begin{array}{l}\mathrm{C}_{\mathrm{th}} \\
(\mathrm{ppm})\end{array}$ & $\begin{array}{l}\mathrm{P}_{\mathrm{vp}} \\
(\mathrm{mmHg})\end{array}$ & Serial No. Odorant & $\begin{array}{l}\mathrm{C}_{\mathrm{th}} \\
(\mathrm{ppm})\end{array}$ & $\begin{array}{l}\mathrm{P}_{\mathrm{vp}} \\
(\mathrm{mmHg})\end{array}$ \\
\hline (Alkane) & & & 12. tt-Amyl alcohol & 0.99 & 13.5 \\
1. n-Pentane & 18 & 510 & 13. n-Hexyl alcohol & 0.032 & 0.81 \\
2. Isopentane & 46 & 685 & 14. n-Heptyl alcohol & 0.0073 & 0.13 \\
3. n-Hexane & 10 & 150 & 15. n-Octyl alcohol & 0.0021 & 0.049 \\
4. Isohexane & 3.4 & 211 & 16. n-Nonyl alcohol & 0.0023 & 0.099 \\
5. 2,2-Dimethyl butane & 120 & 317 & 17. n-Decyl alcohol & 0.00092 & 0.0046 \\
6. n-Heptane & 4.9 & 45.5 & (Ketone) & & \\
7. 2,4-Dimethyl pentane & 4.9 & 97.7 & 1. Acetone & 32 & 228 \\
8. n-Octane & 1.4 & 13.9 & 2. Methyl ethyl ketone & 4.9 & 94.1 \\
9. n-Nonane & 0.4 & 4.25 & 3. Methyl n-propyl ketone & 0.17 & 35.0 \\
10. n-Decane & 0.16 & 1.28 & 4. Methyl i-propyl ketone & 0.60 & 51.7 \\
11. n-Dodecane & 0.012 & 0.12 & 5. Methyl n-butyl ketone & 0.20 & 12.9 \\
(Alcohol) & & & 6. Methyl i-butyl ketone & 0.53 & 19.7 \\
1. Methyl alcohol & 21 & 126 & 7. Methyl sec-butyl ketone & 0.48 & 19.3 \\
2. Ethyl alcohol & 3.8 & 58.6 & 8. Methyl tt-butyl ketone & 0.85 & $31.8 *$ \\
3. n-Propyl alcohol & 0.68 & 20.3 & 9. Methyl n-amyl ketone & 0.018 & 1.37 \\
4. Isopropyl alcohol & 5.7 & 44.8 & 10. Methyl i-amyl ketone & 0.011 & $4.58^{*}$ \\
5. n-Butyl alcohol & 0.20 & 6.09 & 11. Methyl n-hexyl ketone & 0.042 & 1.28 \\
6. Isobutyl alcohol & 0.11 & 10.3 & 12. Diethyl ketone & 0.54 & 86.6 \\
7. sec-Butyl alcohol & 0.84 & 18.0 & 13. Methyl n-heptyl ketone & 0.0090 & 0.733 \\
8. tt-Butyl alcohol & 3.8 & 41.6 & (Aldehyde) & & \\
9. n-Amyl alcohol & 0.16 & 2.32 & 1. Formaldehyde & 0.92 & 3822 \\
10. Isoamyl alcohol & 0.0085 & 3.02 & 2. Acetaldehyde & 0.023 & 895 \\
11. sec-Amyl alcohol & 0.39 & 6.68 & 3. Propionaldehyde & 0.020 & 316 \\
\hline
\end{tabular}


Table 1 Continued

\begin{tabular}{|c|c|c|c|c|c|}
\hline Serial No. Odorant & $\begin{array}{l}\mathrm{C}_{\mathrm{th}} \\
(\mathrm{ppm})\end{array}$ & $\begin{array}{l}\mathrm{P}_{\mathrm{vp}} \\
(\mathrm{mmHg})\end{array}$ & Serial No. Odorant & $\begin{array}{l}\mathrm{C}_{\text {th }} \\
(\mathrm{ppm})\end{array}$ & $\begin{array}{l}\mathrm{P}_{\mathrm{vp}} \\
(\mathrm{mmHg})\end{array}$ \\
\hline 4. n-Butyladehyde & 0.0037 & 111 & 2. Acetic acid & 0.021 & 15.1 \\
\hline 5. Isobutyladehyde & 0.0058 & 171 & 3. Propionic acid & 0.016 & 3.41 \\
\hline 6. $n$-Valeraldehyde & 0.0014 & 34.1 & 4. n-Butanoic acid & 0.00035 & 0.79 \\
\hline 7. Isovaleraldehyde & 0.00063 & $40.5^{*}$ & 5. Isobutanoic acid & 0.00012 & 1.19 \\
\hline 8. n-Hexyladehyde & 0.00035 & 11.6 & 6. $n$-Valeric acid & 0.0016 & 0.18 \\
\hline 9. n-Heptyladehyde & 0.00015 & 4.01 & 7. Isovaleric acid & 0.000063 & 0.56 \\
\hline 10. n-Octylaldehyde & 0.00012 & 1.55 & 8. $n$-Hexanoic acid & 0.0032 & 0.088 \\
\hline 11. n-Nonylaldehyde & 0.000080 & 0.579 & (Aromatic compound) & & \\
\hline (Ester) & & & 1. Benzene & 14 & 94.5 \\
\hline 1. Methyl formate & 31 & 582 & 2. Toluene & 1.3 & 28.7 \\
\hline 2. Ethyl formate & 3.9 & 241 & 3. Ethyl benzene & 0.22 & 9.42 \\
\hline 3. n-Propyl formate & 0.92 & 81.8 & 4. o-Xylene & 0.60 & 6.56 \\
\hline 4. Isopropyl formate & 1.6 & 137 & 5. m-Xylene & 0.76 & 8.23 \\
\hline 5. n-Butyl formate & 0.076 & 28.7 & 6. p-Xylene & 0.36 & 8.68 \\
\hline 6. Isobutyl formate & 0.11 & 32.6 & 7. n-Propyl benzene & 0.0048 & 3.34 \\
\hline 7. Methyl acetate & 2.5 & 215 & 8. 1,2,4-Trimethyl benz. & 0.12 & 2.01 \\
\hline 8. Ethyl acetate & 0.11 & 96.1 & 9. 1,3,5-Trimethyl benz. & 0.075 & 2.39 \\
\hline 9. n-Propyl acetate & 0.047 & 32.6 & 10. n-Butyl benzene & 0.0043 & 1.01 \\
\hline 10. Isopropyl acetate & 0.16 & 59.2 & 11. Methoxy benzene & 0.059 & 3.95 \\
\hline 11. n-Butyl acetate & 0.0036 & 11.2 & 12. Acetophenone & 0.0017 & 0.542 \\
\hline 12. Isobutyl acetate & 0.0032 & 17.0 & 13. Propiophenone & 0.013 & 0.223 \\
\hline 13. sec-Butyl acetate & 0.0038 & $24.0 *$ & 14. Methyl benzoate & 0.017 & 0.543 \\
\hline 14. tert-Butyl acetate & 0.0088 & $45.7 *$ & 15. Nitrobenzene & 0.0036 & 0.368 \\
\hline 15. n-Hexyl acetate & 0.00028 & $1.89 *$ & 16. Benzaldehyde & 0.0019 & 1.33 \\
\hline 16. Methyl propionate & 0.12 & 84.8 & 17. Benzonitrile & 0.0052 & 0.886 \\
\hline 17. Ethyl propionate & 0.0036 & 37.0 & 18. Benzyl alcohol & 0.20 & 0.160 \\
\hline 18. n-Propyl propionate & 0.0018 & 14.0 & 19. Bromobenzene & 0.015 & 4.56 \\
\hline 19. Isopropyl propionate & 0.0060 & $26.3^{*}$ & 20. Chlorobenzene & 0.058 & 11.9 \\
\hline 20. n-Butyl propionate & 0.0024 & $5.38 *$ & 21. Aniline & 0.51 & 3.65 \\
\hline 21. Isobutyl propionate & 0.00026 & 6.72 & (Amine) & & \\
\hline 22. Methyl n-butyrate & 0.010 & 31.4 & 1. Ammonia & 1.2 & 7343 \\
\hline 23. Methyl isobutyrate & 0.0069 & 48.3 & 2. Methyl amine & 0.025 & 2666 \\
\hline 24. Ethyl n-butyrate & 0.0056 & $15.4^{*}$ & 3. Ethyl amine & 0.038 & 1056 \\
\hline 25. Ethyl isobutyrate & 0.0044 & $41.5^{*}$ & 4. $\mathrm{n}$-Propyl amine & 0.047 & 312 \\
\hline 26. n-Propyl n-butyrate & 0.0026 & 6.20 & 5. Isopropyl amine & 0.062 & 572 \\
\hline 27. Isopropyl n-butyrate & 0.0060 & $11.3^{*}$ & 6. n-Butyl amine & 0.052 & 91.0 \\
\hline 28. $\mathrm{n}$-Propyl isobutyrate & 0.0036 & 8.61 & 7. Isobuthyl amine & 0.020 & 143 \\
\hline 29. Isopropyl isobutyrate & 0.0051 & 16.0 & 8. Dimethyl amine & 0.022 & 1468 \\
\hline 30. n-Butyl n-butyrate & 0.0028 & $2.32 *$ & 9. Diethyl amine & 0.061 & 234 \\
\hline 31. Isobutyl $n$-butyrate & 0.0020 & 3.94 & 10. Trimethyl amine & 0.00040 & 1691 \\
\hline 32. $\mathrm{n}$-Butyl isobutyrate & 0.0055 & $3.79 *$ & 11. Triethyl amine & 0.0094 & 67.3 \\
\hline 33. Isobutyl isobutyrate & 0.0023 & 4.43 & (Sulfur compound) & & \\
\hline 34. Methyl n-valerate & 0.0054 & $11.4^{*}$ & 1. Hydrogen sulfide & 0.00089 & 14770 \\
\hline 35. Methyl isovalerate & 0.0010 & 18.6 & 2. Carbon disulfide & 0.20 & 358 \\
\hline 36. Ethyl isovalerate & 0.00023 & 5.74 & 3. Dimethyl sulfide & 0.0053 & 481 \\
\hline 37. Ethyl n-valerate & 0.00025 & 8.30 & 4. Diethyl sulfide & 0.00068 & 57.9 \\
\hline 38. n-Propyl n-valerate & 0.0013 & 3.32 & 5. Dimethyl disulfide & 0.011 & $16.5^{*}$ \\
\hline 39. $\mathrm{n}$-Propyl isovalerate & 0.00011 & $4.00 *$ & 6. Methyl mercaptane & 0.00015 & 1508 \\
\hline 40. $n$-Butyl isovalerate & 0.00014 & $1.48^{*}$ & 7. Ethyl mercaptane & 0.00011 & 524 \\
\hline 41. Isobutyl isovalerate & 0.00032 & 2.03 & 8. n-Propyl mercaptane & 0.000095 & 149 \\
\hline (Acid) & & & 9. n-Butyl mercaptane & 0.000050 & 44.1 \\
\hline 1. Formic acid & 0.46 & 42.2 & 10. Isobutyl mercaptane & 0.000035 & 77.9 \\
\hline
\end{tabular}

* Estimated value on the basis of the relationship of the affinities for phospholipid and the saturated vapor pressures. 
と筆者らが脂質コーティングカラムを用いたガスクロマ トグラフ分析によって測定した保持時間との相関関係を (8)式に基づいて検討した。すなわち，(8)式への回帰式を 求めた結果はTable 2 に示す通りである。いずれも相関 係数は非常に高く，1\%の有意水準で統計的に有意な相 関が得られた。したがって, $\mathrm{P}_{\mathrm{vp}}$ が脂質への吸着, 溶解 性を表す有効な指標となりらることは明らかである。

ところで，各物質の飽和蒸気圧の測定には，アイソテ ニスコープ法 ${ }^{14)}$ および気体流動法 ${ }^{14)}$ が用いられるが, 本研究の解析方法は, ガスクロマトグラフ分析によって 測定された保持時間から, 間接的に飽和蒸気圧を推定す る簡易法としても位置づけられる。すなわち, 飽和蒸気 圧が無極性溶媒への溶解性指標となり得ることを利用し て，ガスクロマトグラフ分析によって得られた保持時間 との関係式である(8)式から飽和蒸気圧を予測する方法で ある。

そこで, $\mathrm{P}_{\mathrm{vp}}$ の得られていない物質については, Table 2 における回䚻式から逆に $\mathrm{P}_{\mathrm{vp}}$ を推定した。推定結果はTable 1中に*印を付して記述した。

Table 2 Regression equation for the linear relationship between $\log k^{\prime 10)}$ and $\log P_{v p}$ in the homologous series. $\alpha$ and $\beta^{\prime}$ represent the regression coefficient and the constant term respectively, in the following equation. $r$ and $\mathrm{n}$ represent the correlation coefficient and the number of data, respectively.

$\log \mathbf{P}_{\mathrm{vp}}=\alpha \log \mathbf{k}^{\prime}-\beta^{\prime}$, where, $\mathbf{P}_{\mathrm{vp}}$ is a saturated vapor pressure and $k$ ' is an indicator of lipid affinity.

\begin{tabular}{lcccc}
\hline Series & $\alpha$ & $\beta^{\prime}$ & $\mathrm{r}$ & $\mathrm{n}$ \\
\hline Alkane & 1.03 & -2.05 & 0.993 & 10 \\
Alcohol & 1.13 & -1.95 & 0.994 & 14 \\
Ketone & 1.11 & -2.16 & 0.964 & 10 \\
Aldehyde & 1.19 & -2.06 & 0.982 & 6 \\
Ester & 0.95 & -2.09 & 0.992 & 28 \\
Aromatic & 1.21 & -2.59 & 0.993 & 18 \\
\hline
\end{tabular}

3. 嗅覚閾值と飽和蒸気圧の相関性

(3)式から $\mathrm{C}_{\mathrm{th}}$ と $\mathrm{P}_{\mathrm{vp}}$ の間には, 次式が成立すると考え られる。

$$
\log \mathrm{P}_{\mathrm{vp}}=\log \mathrm{C}_{\mathrm{th}}+\log \left(\mathrm{A}_{0} / \mathrm{P}\right)
$$

すなわち, $\log \mathrm{P}_{\mathrm{vp}}$ と $\log \mathrm{C}_{\mathrm{th}}$ は傾き 1 の一次直線関係 にあることが考えられることから， $\mathrm{P}_{\mathrm{vp}}$ と $\mathrm{C}_{\mathrm{th}}$ を両対数 紙上にプロットすることによって両者の相関性を検討し た。

両対数紙上に各グループごとの $\mathrm{P}_{\mathrm{vp}}$ と $\mathrm{C}_{\mathrm{th}}$ をプロット
した図がFig. 1 (a) （i)である。脂肪酸類, 硫黄化合物 およびアミン類を除いて，概ね $\log \mathrm{P}_{\mathrm{vp}}$ と $\log \mathrm{C}_{\mathrm{th}}$ は一次 の線形関係にあることが認められる。図中の実線は，1 \%の有意水準で有意な相関が認められたものについて求 めた回帰直線である。これらの回帰式をTable 3 に示す。 有意な相関が得られたグルーブの中で，エステル類を除 けば回帰直線の傾きはほぼ 1 に近く，(9)式への回帰は妥 当であると考えられる。また，回䚻式の定数項は負になっ ているが，(9)式の右辺第 2 項(定数項)と対応させると， 回帰式の定数項の絶対值が大きい汪ど $\mathrm{A}_{0}$ が小さいこと になる( $\mathrm{P}$ は一定)。すなわち， $\mathrm{A}_{0}$ が小さい棌ど，少な い吸着量あるいは溶解量で受容器電位が発生する(にお いを感じる)ことを示している。回帰式の結果より， $\mathrm{A}_{0}$ はエステル類とアルデヒド類が最も小さく， アルカン類 が最も大きい。したがって，受容器電位を発生させるた めに必要な脂質への溶解量は, 相対的にはエステル類お よびアルデヒド類が最も小さく，アルカン類が最も大き いことが推測される。これらの $\mathrm{A}_{0}$ の相違は，各グルー プごとにレセプターが異なり，受容器電位を発生させる ために必要な溶解量が異なるか，あるいは受容タンパク 質の存在を仮定すれば，脂質への溶解後の受容タンパク 質との親和性の相違に由来するものであると推測するこ ともできる。

Table 3 Regression equation for the linear relationship between $\log \mathrm{C}_{\mathrm{th}}$ and $\log \mathrm{P}_{\mathrm{vp}}$ in the homologous series. $C_{\text {th }}$ and $P_{v p}$ are the odor threshold and the saturated vapor pressure, respectively. $r$ and $n$ represent the correlation coefficient and the number of data, respectively.

\begin{tabular}{llcc}
\hline Series & \multicolumn{1}{c}{ Regression equation } & $\mathrm{r}$ & $\mathrm{n}$ \\
\hline Alkane & $\log \mathrm{C}_{\text {th }}=0.92 \log \mathrm{P}_{\mathrm{vp}}-0.98$ & 0.957 & 11 \\
Alcohol & $\log \mathrm{C}_{\text {th }}=1.01 \log \mathrm{P}_{\mathrm{vp}}-1.33$ & 0.943 & 17 \\
Ketone & $\log \mathrm{C}_{\text {th }}=1.18 \log \mathrm{P}_{\mathrm{vp}}-2.00$ & 0.906 & 13 \\
Aldehyde & $\log \mathrm{C}_{\text {th }}=1.00 \log \mathrm{P}_{\mathrm{vp}}-4.32$ & 0.960 & 11 \\
Ester & $\log \mathrm{C}_{\text {th }}=1.18 \log \mathrm{P}_{\mathrm{vp}}-4.31$ & 0.880 & 41 \\
Aromatic & $\log \mathrm{C}_{\mathrm{th}}=1.04 \log \mathrm{P}_{\mathrm{vp}}-1.63$ & 0.719 & 21 \\
\hline
\end{tabular}

また，解離性物質である脂肪酸類およびアミン類につ いては有意な相関関係が得られなかった。また，硫黄化 合物についても同様であった。これらのグループでは, 他に䦭値を規定する因子が存在すると考えられる。

その他, 構造異性体においては, iso体はnormal体よ り $\mathrm{P}_{\mathrm{vp}}$ が大きいにもかかわらず $\mathrm{C}_{\mathrm{th}}$ が小さい傾向が全グ ループを通して認められた。

また，炭素数が増え $\mathrm{P}_{\mathrm{vp}}$ が小さくなるにつれて， $\mathrm{C}_{\mathrm{th}}$ 

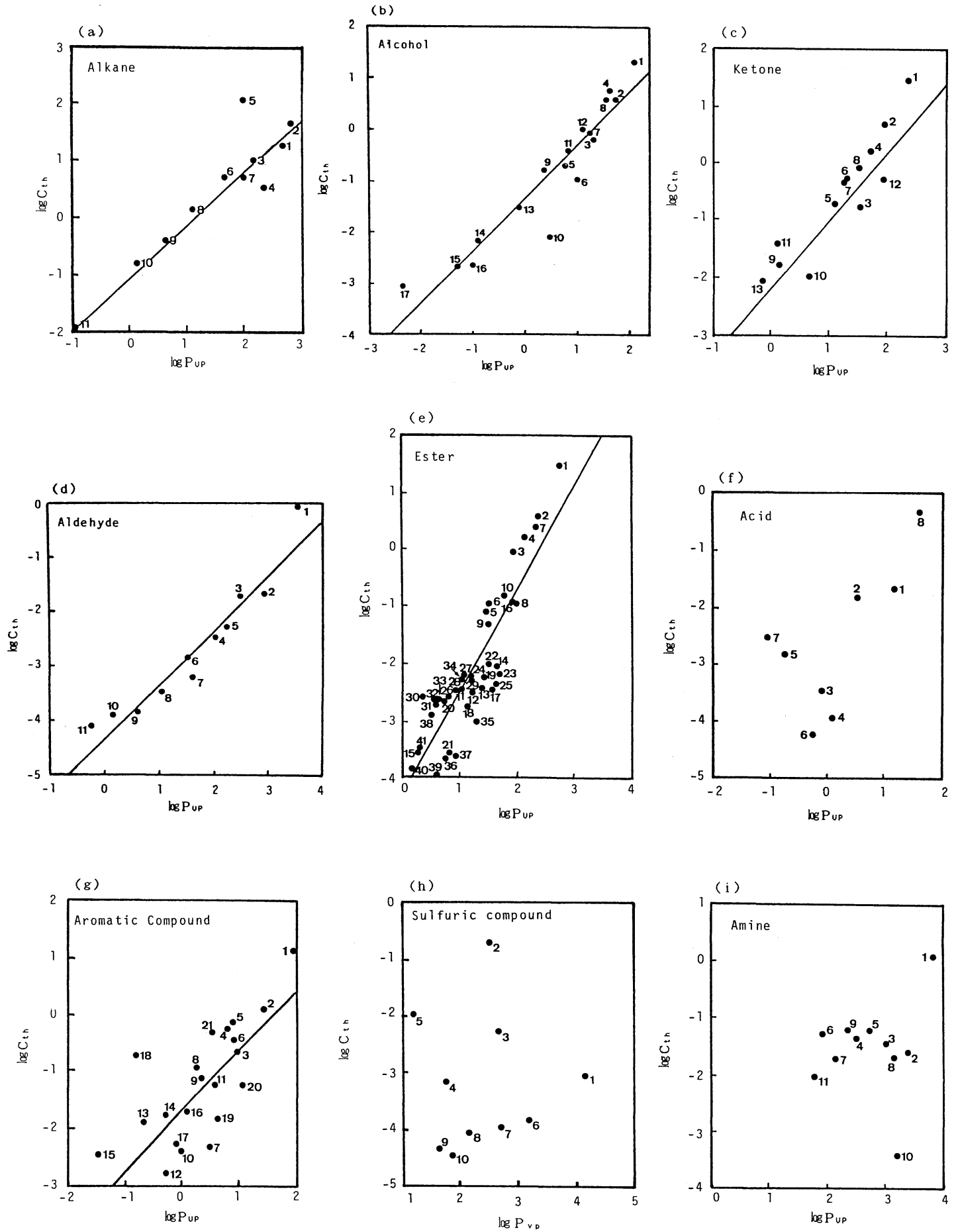

Fig.1 Relationship between $\log C_{\text {th }}$ and $\log P_{v p}$ in homologous series. $C_{\text {th }}$ and $P_{v p}$ represent saturated vapor pressure and odor threshold, respectively. The numbers in each diagram of the homologous series are the same as the serial ones in Table 1. 
の減少の割合が小さくなる傾向，すなわちFig.1のグラ フにおいて， $\mathrm{P}_{\mathrm{vp}}$ が小さくなるほど曲線がフラットにな る傾向がアルコール類とアルデヒド類に認められた。

以上のような $\mathrm{C}_{\mathrm{th}}$ と $\mathrm{P}_{\mathrm{vp}}$ の間の特徵から, 脂肪酸類, 硫黄化合物およびアミン類を除いて，臭気物質の閾値は， おお拈似，脂質のような極性の低い物質層への吸着， 溶解性によって決定されると考えられる。しかしながら， 脂肪酸類, 硫黄化合物およびアミン類で有意な相関性が 認められない点や, 構造異性体における $\mathrm{C}_{\mathrm{th}}$ の違いなど, 脂質への吸着, 溶解性だけでは説明がつかない点も存在 する。すなわち，閾値を決定する因子として，脂質様の 極性の低い物質への吸着, 溶解性以外に関与する因子の 存在が推測される。

そこで, $\mathrm{P}_{\mathrm{vp}}$ 以外に $\mathrm{C}_{\mathrm{th}}$ に関与する物理化学的特性値 を見い出すために, 各臭気物質の $\mathrm{C}_{\mathrm{th}}$ と化学構造の関係 を考慮して，さらに詳細に傾向を抽出した。各グループ ごとに検討した結果は次の通りである。

1) アルカン類

Fig. 1 (a)より, $\log \mathrm{P}_{\mathrm{vp}}$ と $\log \mathrm{C}_{\mathrm{th}}$ の間には，ほぼ 一次の線形関係が成立すると考えられる。しかしなが ら, No.5 (2,2-Dimethyl butane) が極端にC $\mathrm{th}_{\mathrm{h}}$ が大き く，また，No.3 (n-Hexane) とNo.4 (Isohexane)では, iso 体の方がnormal体より $\mathrm{C}_{\mathrm{th}}$ が小さい。

2) アルコール類

Fig.1 (b)において $\log \mathrm{P}_{\mathrm{vp}}$ と $\log \mathrm{C}_{\mathrm{th}}$ は一次の線形 関係にあるが，No.6のIsobutylalcohol とNo.10の Isoamylalcohol のiso 体がnormal 体に比較してC $\mathrm{th}_{\mathrm{th}}$ が 小さく，回帰直線より下方へずれる。しかしNo.4の Isopropylalcohol は注济回帰直線上に位置している。 また，No.17のDecylalcohol が回帰直線より上方にず れ, $\log \mathrm{P}_{\mathrm{vp}}$ が小さくなるにつれて $\log \mathrm{C}_{\mathrm{th}}$ の減少の割 合が小さくなる傾向が認められる。

3 ) ケトン類

Fig.1 (c)より $\log \mathrm{P}_{\mathrm{vp}}$ と $\log \mathrm{C}_{\mathrm{th}}$ は， ほぼ一次の線 形関係にあるが，No.3のMethyl n-propyl keton, No.10 のMethyl isoamyl ketone およびNo.12のDiethyl ketone のC $\mathrm{th}_{\mathrm{th}}$ が小さ。

4) アルデヒド類

Fig.1 (d)より, 回帰直線への相関は高いが， $\mathrm{P}_{\mathrm{vp}}$ が小さくなるにつれて $\log \mathrm{P}_{\mathrm{vp}}$ に対する $\log \mathrm{C}_{\mathrm{th}}$ の減少 の割合は小さくなっている。構造異性体についてみる と, No.6のn-ValeraldehydeよりNo.7のIsovaleraldehyde

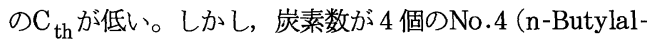
dehyde) とNo.5 (Isobutylaldehyde)では, iso 体の方 がnormal体より $\mathrm{C}_{\mathrm{th}}$ が小さい傾向は認められなかっ た。

5 ) エステル類

Fig.1 (e)より, $\log \mathrm{P}_{\mathrm{vp}}$ と $\log \mathrm{C}_{\mathrm{th}}$ の間にはほぼ一 次の線形関係が成立する。また，構造異性体について みると，エステル類を $\mathrm{R}_{1} \mathrm{COOR}_{2}$ と表すとき. 炭素数 が 5 個以上の場合の $R_{1}$ では, iso体の場合がnormal 体に比較して $\mathrm{C}_{\mathrm{th}}$ が小さいか，あるいは同程度になる 傾向が認められる。例えば, No.22 (Methyl n-butyrate) とNo.23 (Methyl isobutyrate), およびNo.34 (Methyl n-valerate) とNo.35 (Methyl isovalerate) でiso 体の 方がnormal体より $\mathrm{C}_{\mathrm{th}}$ が小さい。 $\mathrm{R}_{2}$ では影著な傾向 は認められない。

\section{6 ) 脂肪酸類}

Fig.1 (f)より, 炭素数が 4 以下では $\log \mathrm{P}_{\mathrm{vp}}$ と $\log$ $\mathrm{C}_{\mathrm{th}}$ の間には一次の線形関係があるとも考えられるが, No.6 (n-Valeric acid) およびNo.8 (n-Hexanoic acid) では， $\mathrm{P}_{\mathrm{vp}}$ が減少するにつれて逆に $\mathrm{C}_{\mathrm{th}}$ は大きくなる。 また，構造異性体についてみると，No.4 (n-Butanoic acid) とNo.5 (Isobutanoic acid), およびNo.6 (n-Valeric acid) とNo.7 (Isovaleric acid) では，iso体の方がnormal 体より極端に $\mathrm{C}_{\mathrm{th}}$ が小さい。

\section{7 ) 芳香族類}

Fig.1 (g)より， 概そ $\mathrm{P}_{\mathrm{vp}}$ の減少に伴って $\mathrm{C}_{\mathrm{th}}$ も小さ くなるが，No.18 (Benzyl alcohol)などは直線から極 端に離れている。構造上の特徵や置換基の電子的効果 との関連性は明確ではない。

8 ) 硫黄化合物

Fig.1 (h)より, $\log \mathrm{P}_{\mathrm{vp}}$ と $\log \mathrm{C}_{\mathrm{th}}$ の間には明確な 傾向は認められない。しかしながら，スルフヒドリル 基(一SH)を有するNo.1の硫化水素およびNo.6〜10の メルカプタン類のみを考えた場合， $\log \mathrm{P}_{\mathrm{vp}}$ が小さく なるとともに, $\log \mathrm{C}_{\mathrm{th}}$ も減少している。本実験では, 硫黄原子を含むものを硫黄化合物として同じグループ に分類したが，閾値と物理化学的特性との相関性を検 討する場合には，適切な分類とは言えないとも考えら れる。

9) アミン類

Fig.1 (i)より, $\log \mathrm{P}_{\mathrm{vp}}$ と $\log \mathrm{C}_{\mathrm{th}}$ の間には明確な 傾向は認められない。しかしながら，大まかにみると 窒素原子に結合するアルキル基の数が多いほど $\mathrm{C}_{\mathrm{th}}$ が 小さく，アルキル基の数が同じ場合は，アルキル基の 炭素数が少ないほど $\mathrm{th}_{\text {th }}$ は小さい。すなわち. $\mathrm{C}_{\mathrm{th}}$ の 大きさは，アルキル基がメチル基の場合 $\left(\mathrm{CH}_{3}\right)_{3} \mathrm{~N}<\left(\mathrm{CH}_{3}\right)_{2}$ 
$\mathrm{NH}<\mathrm{CH}_{3} \mathrm{NH}_{2}$ となり. アルキル基の数が 1 個の場合， $\mathrm{CH}_{3} \mathrm{NH}_{2}<\mathrm{C}_{2} \mathrm{H}_{5} \mathrm{NH}_{2}<\mathrm{C}_{3} \mathrm{H}_{7} \mathrm{NH}_{2}<\mathrm{C}_{4} \mathrm{H}_{9} \mathrm{NH}_{2}$, アルキル 基の数が 2 個の場合, $\left(\mathrm{CH}_{3}\right)_{2} \mathrm{NH}<\left(\mathrm{C}_{2} \mathrm{H}_{5}\right)_{2} \mathrm{NH}$, アル キルの数が 3 個の場合， $\left(\mathrm{CH}_{3}\right)_{3} \mathrm{~N}<\left(\mathrm{C}_{2} \mathrm{H}_{5}\right)_{3} \mathrm{~N}$ となる。 これらの傾向には, 窒素原子の電子供与性や反応に対 する立体障害が関係していると考えられ. 現在検討中 である。

このよらに，1） 9) で各グループことに詳細に検討 すると. 閾值の決定因子として脂質層への吸着, 溶解性 以外に関与する因子の存在が考えられ，ここまでの結果 を総合すると次の(1)〜(4)の傾向を有する因子にまとめら れる。

(1)脂肪酸を除く脂肪族化合物類において, $\log \mathrm{P}_{\mathrm{vp}}$ と $\log$ $\mathrm{C}_{\text {th }}$ の間に成立する直線関係が族間で異なる。

(2)炭素数がある程度の数以上では, normal体より iso 体 の閾值が低い。

(3)アミン類においては，窒素原子に結合するアルキル基 の数が多いほど $\mathrm{C}_{\mathrm{th}}$ が小さく，アルキル基の数が同じ 場合は, アルキル基の炭素数が少ないほど $\mathrm{C}_{\mathrm{th}}$ は小さ W。

(4)アルコールやアルデヒド類に認められたように, $\mathrm{P}_{\mathrm{vp}}$ が小さくなるにつれて, $\log \mathrm{P}_{\mathrm{vp}}$ に対する $\log \mathrm{C}_{\mathrm{th}}$ の減 少する割合が小さくなる。また, 脂肪酸では逆に炭素 数が 5 個以上になると $\mathrm{C}_{\mathrm{th}}$ が大きくなる。

したがって，ヒトの閾值は，これらの幾つかの影響因 子が相互に関与し合って決定されると推測され, 今後, (1)〜(4)の傾向を誘引している分子の構造特性の検索が必 要である。

\section{結語}

臭気物質の物理化学的性状から嗅覚閾值を予測する手 法の開発を目的として, 脂質への溶解性指標としての飽 和蒸気圧と閾值との相関性を検討した。本研究によって 得られた知見を要約すると次の通りである。

1 ) 飽和蒸気圧 $\left(\mathrm{P}_{\mathrm{vp}}\right)$ が無極性溶媒への理想溶解度を表 す指標であることから，脂質層への溶解性指標となり 得ることを示唆した。また, 脂質コーティング剂充填 カラムを装着したガスクロマトグラフ分析装置によっ て測定した保持時間と, $\mathrm{P}_{\mathrm{vp}}$ との関係を検討した結果, 高い相関が得られたことから． $\mathrm{P}_{\mathrm{vp}}$ が脂質への溶解能 を表す指標となり得ることが明らかとなった。

$2) \mathrm{P}_{\mathrm{vp}}$ と閾值 $\left(\mathrm{C}_{\mathrm{th}}\right)$ の相関性を検討した結果, 脂肪族 化合物類の同族列内で高い相関性が認められた。しか し, 解離物質である脂肪酸類とアミン類, および硫黄
化合物では相関が認められなかったことから，これら の物質では閾値を規定する因子として，脂質への吸着， 溶解性以外の因子が関与していることが考えられた。

3 ) 同族列内でも構造異性体間では, 炭素数が $3 \sim 5$ 以 上でiso 体の方がnormal 体より閾值が小さくなる傾向 が認められた。

4 ) アミン類では窒素原子に結合するアルキル鎖とその 数によって特徵的な傾向が認められた。

5 ) アルコールおよびアルデヒド類では， $\mathrm{P}_{\mathrm{vp}}$ が小さく なると $\mathrm{C}_{\mathrm{th}}$ の減少する割合が小さくなる傾向が認めら れた。

以上の結果から, 明らかに閾値を規定する因子は複数 あることが考えられる。あた，各族ごとに閾值を規定す る因子が異なり, 特にアミン類や脂肪酸類のような解離 性の物質は, 脂質への吸着, 溶解性と閾值との間に相関 性がないことから, 他の族と全く異なる受容機構が存在 する可能性も高い。

今後, 以上の結果を踏まえて, におい分子とレセプター 分子との結合性などを表し得るような電子的および立体 的パラメーターと閾值の相関性の検討を行う予定である。

なお, 本論文の一部は, 第60回日本衛生学会総会(福 岡)にて発表した。

\section{文献}

1 ) 石黒辰吉, 岩崎好陽, 福島 悠, 小野塚春吉 : 三点 比較式臭袋法の実施要綱, 悪臭の研究, 12, 31-36 (1973).

2 ) 西田耕之助：臭気の評価方法に関する知識と情報, 臭気の研究, 19，359-367 (1988).

3 ) Leonardos, G., Kendall, D. and Barnard, N.: Odor threshold determination of 53 odorant chemicals, J. Air Pollu. Control Assoc., 19, 91-95 (1965).

4 ) Dravnieks, A. and Laffort, P. : 西田耕之助, 石 川義紀共訳：化学分析による臭気強度之質の予測に 対する可能性 (II), 悪臭の研究, 15，24-30 (1974).

5 ) Dravnieks, A.: Building block model for the characterizing odorant molecules and their odors, Ann. N. Y. Acad. Sci., 237, 144-163 (1974).

6 ) Laffort, P.: Essai de standarddisation des seuils olfactifs humains pour 192 corps purs, Arch. Sci. Physiol., 17, 75-105 (1963), cited in 5).

7 ) Kashiwayanagi, M. and Kurihara, K.: Evidence for non-receptor odor discrimination using neuroblastoma cells as model for olfactory cells, Brain Res. , 359, 
97-103 (1985).

8 ) Nomura, T. and Kurihara, K.: Effects of changed lipid composition on responses of liposomes to various odorants: Possible mechanism of odor discrimination, Biochemistry, 23, 6141-6145 (1987).

9 ) 岡畑恵雄 : 水晶発振を利用した匂いセンサー, 臭気 の研究, 20, 252-256 (1989).

10）大迫政浩, 西田耕之助, 松井三郎：臭気物質の物理 化学的特性に基づく嗅覚閾値の推定方法の検討(第 1 報) 一脂質親和性との関連性一, 大気污染学会誌, 25, 405-414 (1990).

11）R.C.リード，J.M.ブラウズニッツ，T.K.シャー
ウッド著：平田光穗監訳 : 気体, 液体の物性推算ハ ンドブック，マグロウヒル，東京（1985）.

12）日本化学会編：化学便覧(基礎編), p. 708 731, 丸善, 東京 (1975).

13）寺田 弘：高速液体クロマトグラフィーによる蹯水 性パラメータ, 藤田稔夫編, 構造活性相関とドラッ クデザイン, 化学増刊, 107, p.65-78, 化学同人, 京都 (1986).

14）日本環境協会編：化学物質の物理化学性状測定法, p. 23 74, 産業図書, 東京 (1987).

（受付 1991年 1 月 7 日 受理 1991年 5 月 23 日） 